\title{
IgG and IgM anti-snRNP reactivity in sequentially obtained serum samples from patients with connective tissue diseases
}

\author{
Ulf Nyman, Ingrid Lundberg, Eva Hedfors, Marie Wahren, Ingvar Pettersson
}

\begin{abstract}
Sequentially obtained serum samples from 30 patients with connective tissue disease positive for antibody to ribonucleoprotein (RNP) were examined to determine the specificities of IgG and IgM antibodies to snRNP during the disease course using immunoblotting of nuclear extracts. The antibody patterns were correlated with disease activity. The patterns of antibody to snRNP of individual patients were mainly stable during the study but changes in levels of antibody to snRNP were seen corresponding to changes in clinical activity. These results indicate that increased reactivity of serum IgM antibodies against the $\mathbf{B} / \mathbf{B}^{\prime}$ proteins seems to precede a clinically evident exacerbation of disease whereas IgG antibody reactivity to the $70 \mathrm{~K}$ protein peaks at the time of a disease flare.
\end{abstract}

(Ann Rheum Dis 1992; 51: 1307-1312)

Autoantibodies reacting with different nuclear and cytoplasmic constituents are characteristically found in serum samples from patients with connective tissue diseases. The presence of some of these autoantibodies is associated with particular clinical manifestations. ${ }^{1}$ High serum titres of IgG antibodies reacting with a ribonucleoprotein (RNP) antigen was thus included as one of the defining criteria of mixed conective tissue disease in a group of patients with connective tissue disease sharing clinical features with systemic lupus erythematosus, progressive systemic sclerosis, and polymyositis. ${ }^{2}$ Autoantibodies to RNP are also found in serum samples from patients with SLE but usually in lower titres and often associated with antibodies of another specificity designated antibodies to Sm. ${ }^{3}$

Antibodies to RNP and $\mathrm{Sm}$ react with Department of Karolinska Institutet, Box 60400, S-104 01 Stockholm, Sweden

U Nyman

$M$ Wahren

I Pettersson

Department of

Rheumatology,

Huddinge University

Hospital,

S-141 86 Huddinge,

Sweden

I Lundberg

E Hedfors

Correspondence to:

Dr Nyman.

Accepted for publication

5 June 1992 to RNP and $\mathrm{Sm}$ in serum samples and certain clinical findings. ${ }^{12-15}$ Statistically significant correlations between reactivity against specific
With at least five different RNP and Sm antigenic snRNP proteins identified, investigators have re-examined the initially observed
snRNP proteins and the presence of certain clinical symptoms and signs have been reported. $^{8} 10 \quad 14 \quad 16-19$ In one longitudinal study decreasing titres of antibodies to RNP were found in patients with connective tissue disease in prolonged clinical remission following intensive treatment with corticosteroids and cytotoxic drugs, indicating an association between changes in clinical manifestations and changes in antibody titre. 9 In another longitudinal study of patients with connective tissue disease with mild disease and few occasions of exacerbation of disease a clearcut correlation between changes in antibody titre and clinical activity was not found. ${ }^{17}$ This indicates that apart from methodological differences in the detection of autoantibodies patient selection is crucial and greatly affects the outcome of different studies.

The aim of this investigation was to study the specificities of antibodies to snRNP in sequentially obtained serum samples during the disease course of patients positive for antibody to RNP. The patients were initially selected only on the basis of being positive for antibody to RNP and were then followed up regularly. A further purpose of this longitudinal study was to analyse whether changes in antibodies to snRNP of both the IgG and IgM isotypes were correlated to changes in disease activity.

\section{Patients and methods}

PATIENTS

Between 1980 and 1989 serum samples from patients admitted to the department of rheumatology, Huddinge University Hospital with symptoms or signs indicating inflammatory connective tissue disease were analysed for the presence of antinuclear antibodies at the department of clinical immunology, Huddinge University Hospital. All serum samples showing a speckled nuclear immunofluorescence pattern were routinely analysed by counterimmunoelectrophoresis for the presence of antibodies reacting with ribonuclease sensitive ribonucleoprotein. Serum samples positive by counterimmunoelectrophoresis were sequentially obtained from 30 patients ( 24 women and six men). The table summarises clinical data and the characterisation of the patients, which has been reported previously. ${ }^{15}$ Exacerbation of disease or 'flare' was defined as the appearance of new or deterioration of current clinical manifestations, or laboratory tests indicating additional or progressive organ disease-that is, chest radiographs, haematological data, muscle enzymes, kidney function tests, and urine analyses. 
DETECTION OF SNRNP POLYPEPTIDE ANTIGENS BY IMMUNOBLOTTING

The various snRNP polypeptides were identified as described previously ${ }^{20}$ on immunoblots with nuclear extracts made from HeLa cells as the antigen source.

\section{DETECTION OF 70K RECOMBINANT ANTIGEN BY} IMMUNOBLOTTING

An Escherichia coli extract containing a recombinant $70 \mathrm{~K}$ fusion protein corresponding to amino acid residues $63-194$ in the $70 \mathrm{~K}$ sequence was used as a source of antigen for immunoblotting. ${ }^{20}$

\section{DENSITOMETRY OF IMMUNOBLOT STRIPS}

To measure the differences in staining intensity seen on the immunoblot strips they were scanned using computed image analysis for densitometry. Each series of serum samples was used to generate at least three sets of immunoblot strips and each set was analysed on more than one occasion. Staining with the same serum sample on different occasions and rescanning immunoblot strips gave reproducible results. The intensity of staining on the immunoblot strips was registered by a Pasecon video camera (Grundig). The signal was transferred to and processed in a Zeiss/Kontron IBAS image analysis computer. Briefly, sections of each individual band on the immunoblot strips were laterally limited ensuring a uniform measurement of the staining intensity. Within the square formed, the area was measured, and the number of pixels and the grey value of each individual pixel was determined. The summarised grey value was computed, expressed in arbitrary units (A.U.) and used in graphs as a quantitative measurement of the staining. The range from a barely visible to a maximally strong band corresponded approximately to a difference between 50 and 1000 A.U.

\section{Results}

DETECTION OF SNRNP POLYPEPTIDE ANTIGENS BY IMMUNOBLOTTING OF SEQUENTIALLY OBTAINED SERUM SAMPLES POSITIVE FOR ANTIBODY TO RNP Most of the serum samples contained IgG and IgM antibodies reacting with one or several of the snRNP proteins on some occasion. A characteristic discrepancy in the recognition pattern of the two isotypes was seen in most samples, however (figs $1 \mathrm{~A}$ and $1 \mathrm{~B}$ ).

\section{REACTIVITY OF IgG ANTIBODIES TO snRNP}

The Western blot results obtained showed that 26 of 30 series of serum samples reacted with the $70 \mathrm{~K}$ protein at some point. Serum samples reacted less often with the $A, B / B^{\prime}$ and $C$ polypeptides (table).

The blots of each individual series of serum samples showed a characteristic pattern recognising one or several snRNP proteins (figs 1A and $1 B$ ). Immunoblotting with the same series of serum samples against recombinant $70 \mathrm{~K}$ protein produced the same qualitative relation between the different serum samples but the signal obtained was much stronger (fig 1C).

Seven series of serum samples did not change substantially in levels of staining intensity or recruitment of new specificities between the observation points. The remaining series showed more obvious changes with respect to levels of reactivity towards the snRNP proteins. Examples of three such profiles are shown (figs $2-4)$. An increasing reaction against the $70 \mathrm{~K}$

Summary of clinical and serological data on the 30 patients positive for antibody to RNP

\begin{tabular}{|c|c|c|c|c|c|c|c|c|c|c|c|c|}
\hline \multirow{2}{*}{$\begin{array}{l}\text { Patient } \\
\text { No }\end{array}$} & \multirow[t]{2}{*}{ Diagnosis } & \multirow{2}{*}{$\begin{array}{l}\text { Length of } \\
\text { study period } \\
\text { (months) }\end{array}$} & \multirow{2}{*}{$\begin{array}{l}\text { No of } \\
\text { observations }\end{array}$} & \multirow[t]{2}{*}{ Drugs } & \multicolumn{4}{|l|}{$\operatorname{Ig}(i$} & \multicolumn{4}{|l|}{$I g M$} \\
\hline & & & & & $70 K$ & $A$ & $B / B^{\prime}$ & $C$ & $70 K$ & $A$ & $B / B^{\prime}$ & $C$ \\
\hline $\begin{array}{r}1 \\
2 \\
3 \\
4 \\
5 \\
6 \\
7 \\
8 \\
9 \\
10 \\
11 \\
12 \\
13 \\
14 \\
15 \\
16 \\
17 \\
18 \\
19 \\
20 \\
21 \\
22 \\
23 \\
24 \\
25 \\
26 \\
27 \\
28 \\
29 \\
30\end{array}$ & $\begin{array}{l}\text { MCTD } \\
\text { MCTD } \\
\text { MCTD } \\
\text { UCTD } \\
\text { MCTD } \\
\text { MCTD } \\
\text { JCA } \\
\text { MCTD } \\
\text { UCTD } \\
\text { MCTD } \\
\text { MCTD } \\
\text { Prim. SS } \\
\text { UCTD>SLE } \\
\text { MCTD } \\
\text { MCTD } \\
\text { MCTD } \\
\text { MCTD } \\
\text { MCTD } \\
\text { MCTD } \\
\text { RA+SS } \\
\text { SLE+MCTD } \\
\text { MCTD } \\
\text { MCTD } \\
\text { Prim. SS } \\
\text { MCTD } \\
\text { SLE } \\
\text { Raynaud } \\
\text { SLE } \\
\text { PSS } \\
\text { SLE }\end{array}$ & $\begin{array}{l}70 \\
21 \\
68 \\
38 \\
52 \\
16 \\
10 \\
21 \\
41 \\
62 \\
52 \\
54 \\
85 \\
66 \\
69 \\
34 \\
15 \\
9 \\
7 \\
30 \\
40 \\
20 \\
22 \\
47 \\
47 \\
31 \\
59 \\
59 \\
11 \\
45\end{array}$ & $\begin{array}{r}12 \\
8 \\
12 \\
9 \\
12 \\
2 \\
2 \\
11 \\
13 \\
7 \\
11 \\
11 \\
12 \\
7 \\
22 \\
13 \\
3 \\
3 \\
4 \\
4 \\
9 \\
6 \\
4 \\
7 \\
10 \\
3 \\
7 \\
11 \\
4 \\
7\end{array}$ & $\begin{array}{l}\text { P } \\
\text { P } \\
\text { P } \\
\text { Cy, P, A } \\
\text { Ch, P } \\
\text { Ch, P } \\
\text { P, A } \\
\text { Ch } \\
\text { Ch, P } \\
\text { P, A } \\
\text { P } \\
\text { P }\end{array}$ & 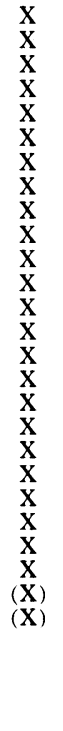 & $\begin{array}{c}\mathbf{X} \\
\mathbf{X} \\
\mathbf{X} \\
\underset{\mathbf{X}}{(\mathbf{X}}) \\
\underset{\mathbf{X}}{(\mathbf{X})} \\
(\underset{\mathbf{X}}{\mathbf{X}}) \\
\underset{(\mathbf{X}}{\mathbf{X}}) \\
(\mathbf{X})\end{array}$ & $\begin{array}{c}\mathbf{X} \\
(\mathbf{X}) \\
\mathbf{X} \\
\mathbf{X} \\
(\mathbf{X}) \\
(\mathbf{X})\end{array}$ & $\begin{array}{c}\mathbf{X} \\
\mathbf{X} \\
\mathbf{X} \\
\mathbf{X} \\
\mathbf{X} \\
(\mathbf{X}) \\
(\mathbf{X}) \\
(\mathbf{X}) \\
\mathbf{X} \\
(\mathbf{X}) \\
\mathbf{X} \\
\mathbf{X} \\
\mathbf{X} \\
\mathbf{X} \\
\mathbf{X} \\
(\mathbf{X}) \\
\mathbf{X} \\
\mathbf{X} \\
\mathbf{X} \\
\mathbf{X} \\
\mathbf{X}\end{array}$ & $\begin{array}{l}\mathrm{X} \\
\mathrm{X} \\
\mathrm{X} \\
\mathrm{X}\end{array}$ & $\begin{array}{c}(\mathbf{X}) \\
\mathbf{X} \\
\mathbf{X} \\
\mathbf{X} \\
\mathbf{X} \\
\mathbf{X} \\
\mathbf{X} \\
\mathbf{X} \\
\mathbf{X} \\
\mathbf{X} \\
\mathbf{X} \\
\mathbf{X} \\
\mathbf{X} \\
\mathbf{X} \\
\mathbf{X} \\
(\mathbf{X})\end{array}$ & $\begin{array}{l}\mathbf{X} \\
\mathbf{X} \\
\mathbf{X} \\
\mathbf{X} \\
\mathbf{X} \\
\mathbf{X} \\
\mathbf{X} \\
\mathbf{X} \\
\mathbf{X} \\
\mathbf{X} \\
\mathbf{X} \\
\mathbf{X} \\
\mathbf{X} \\
\mathbf{X} \\
\mathbf{X} \\
\mathbf{X} \\
\mathbf{X} \\
\mathbf{X} \\
\mathbf{X} \\
\mathbf{X} \\
\mathbf{X} \\
(\mathbf{X}) \\
(\mathbf{X})\end{array}$ & $\begin{array}{c}\mathbf{X} \\
\mathbf{X} \\
\mathbf{X} \\
\mathbf{X} \\
\mathbf{X} \\
\mathbf{X} \\
\mathbf{X} \\
(\mathbf{X}) \\
\mathbf{X} \\
(\mathbf{X}) \\
\mathbf{X} \\
\mathbf{X} \\
\mathbf{X} \\
\mathbf{X} \\
\mathbf{X} \\
\mathbf{X} \\
\mathbf{X} \\
(\mathbf{X}) \\
\mathbf{X} \\
(\mathbf{X}) \\
\mathbf{X} \\
\mathbf{X}\end{array}$ \\
\hline
\end{tabular}

Diagnoses: $M C T D=$ mixed connective tissue disease, UCTD= undefined connective tissue disease, JCA=iuvenile chronic arthritis, Prim. SS = primary Sjögren's syndrome, SLE =systemic lupus erythematosus, RA=rheumatoid arthritis, $S S=$ Siögren's syndrome, Raynaud = Raynaud's phenomenon, PSS=progressive systemic sclerosis. Drug abbreviations: A=azathioprine, $\mathrm{Ch}=\mathrm{chloroquin}$ snRNP proteins $70 \mathrm{~K}, \mathrm{~A}, \mathrm{~B} / \mathrm{B}^{\prime}$, and $\mathrm{C}$ are indicated by $\mathrm{X}=$ strong signals and $(\mathrm{X})=$ weak signals. 
protein was accompanied by an increasing reaction against the other snRNP proteins and sometimes by a recruit of new antibodies against the other snRNP proteins. The reverse situation with decreasing reactivity against the $70 \mathrm{~K}$ protein was paralleled by a decreased reactivity or loss of reactivity against the other snRNP proteins.

It was not possible to establish any obvious correlation in terms of ordered increase or decrease of $A, B / B^{\prime}$, and $C$ staining intensity in relation to fluctuations of the levels of activity against the $70 \mathrm{~K}$ protein.

\section{REACTIVITY OF IgM ANTIBODIES TO SnRNP} In contrast to the IgG results most serum samples showed weak or no IgM reactivity against the $70 \mathrm{~K}$ protein. Almost all the serum samples positive for antibodies to RNP contained
IgM antibodies directed against predominantly $B / B^{\prime}$ (26 of 30 samples) and also against $A$ and C snRNP polypeptides (table). As for the IgG antibodies it was possible to distinguish between series of serum samples with minor (fig 2) or more pronounced (figs 3 and 4) variations in total reactivity against the snRNP proteins. An increasing reaction against the $B / B^{\prime}$ protein was correlated with a shift in reactivity against the other snRNP proteins and with recruitment of new antibody specificities against the other snRNP proteins. The reverse situation, with decreasing reactivity against the $B / B^{\prime}$ protein, was paralleled by a decreased reactivity or loss of reactivity against the other snRNP proteins. It was not possible to establish any ordered correlation in terms of increased or decreased $70 \mathrm{~K}, \mathrm{~A}$, and $\mathrm{C}$ staining intensity in relation to fluctuations of the level of reactivity against $\mathrm{B} / \mathrm{B}^{\prime}$ protein.

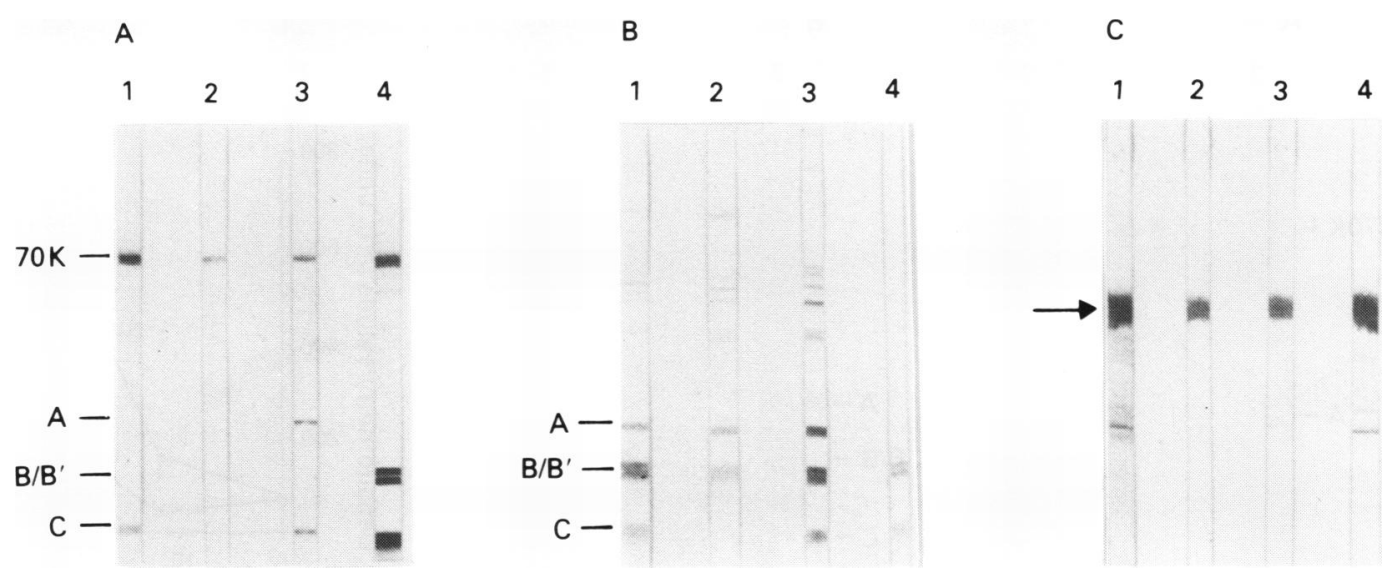

Figure 1 Detection of snRNP polypeptide antigens by immunoblotting. (A) IgG antibodies reactive with snRNP polypeptide antigens in HeLa cell nuclear extract. (B) IgM antibodies reactive with snRNP polypeptide antigens in $H e L a$ cell nuclear extract. (C) IgG antibodies reactive with recombinant 70K antigen. Lane 1: serum sample from patient 2 (table). Lane 2: serum sample from patient 11 (table). Lane 3: Serum sample from patient 16 (table). Lane 4: serum sample from patient 4 (table).

A

$\begin{array}{llllllll}1 & 2 & 3 & 4 & 5 & 6 & 7 & 8\end{array}$

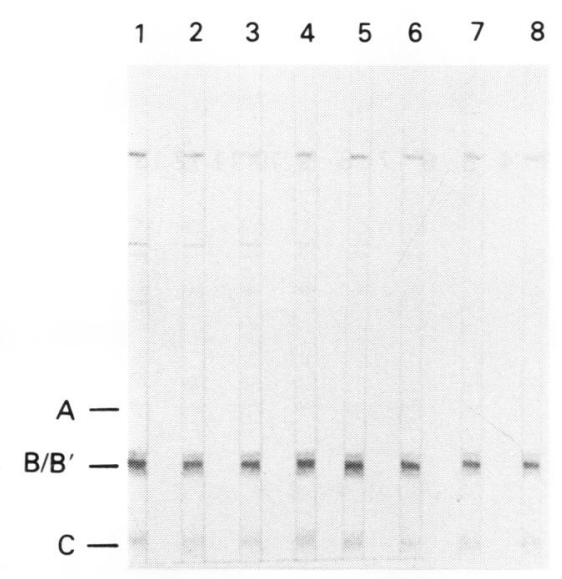

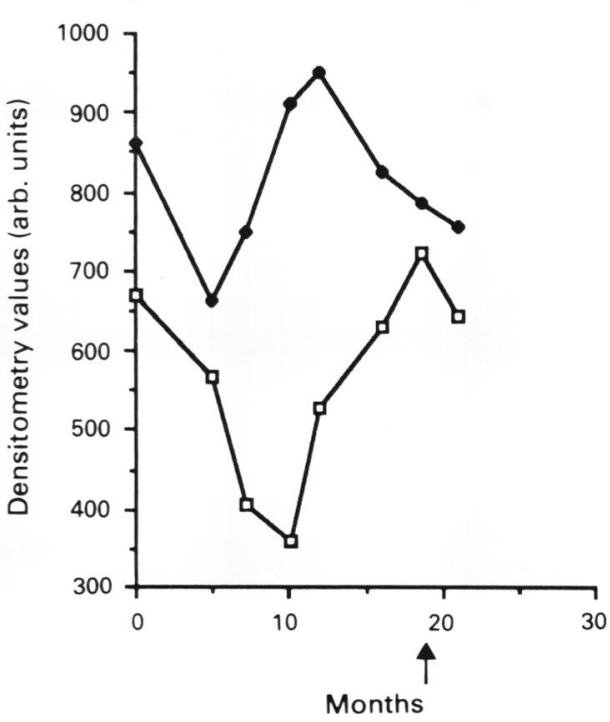

Figure 2 Detection of snRNP polypeptide antigens with sequentially obtained serum samples from patient 2 (table). (A) IgG antibodies reactive with snRNIP polypeptide antigens in $\mathrm{HeL}$ a cell nuclear extract. (B) IgM antibodies reactive with snRNP polypeptide antigens in HeL a cell nuclear extract. (B) IgM antibodies reactive with snRNP polypeptide antigens in HeL a cell nuclear extract. $(C)$ Plot of densitometry values in arbitrary units (arb. units) obtained by scanning the blots shown in $(A)$ and $(B)$. ( $\square)$ IgG antibodies reactive with the $70 K$ protein; $(>)$ IgM antibodies reactive with the B/B' protein. Arrow denotes a timepoint when exacerbation of the disease was first noted. Patient 2 has a relatively mild disease and did not receive drug treatment during the observation period. 
RELATIONSHIP BETWEEN ANTIBODIES TO SNRNP OF IgG AND IgM CLASSES

Antibodies to snRNP of IgG and IgM classes were present in serum samples for an extended period of time, often several years, but with different specificities. Most serum samples showed a high and longstanding IgG reactivity against the $70 \mathrm{~K}$ protein, but a low or absent IgM reactivity. A minority of IgG antibodies reacted against $B / B^{\prime}$, which was the major specificity of the IgM antibodies. In addition to being the most commonly recognised snRNP antigen for IgM antibodies $\mathrm{B} / \mathrm{B}^{\prime}$ was also the antigen against which IgM antibodies showed the greatest variation in reactivity. IgM antibodies towards $B / B^{\prime}, A$, and $C$ protein could exist independently or coexist with IgG antibodies directed towards the same proteins (table).
Serum samples with unchanged reactivity of IgG antibodies also exhibited constant reactivity of IgM antibodies. In the patients with variable reactivity against snRNP antigens, however, integrated optical density measurements of Western blots were performed on the $70 \mathrm{~K}$ and $\mathrm{B} / \mathrm{B}^{\prime}$ bands visualised by IgG and IgM antibodies respectively. These plots showed changing levels of $\operatorname{IgM~} \mathrm{B} / \mathrm{B}^{\prime}$ staining intensity preceding a corresponding change in $\mathrm{IgG} 70 \mathrm{~K}$ staining intensity. The $\operatorname{IgM} B / B^{\prime}$ changes were manifest several weeks before the IgG $70 \mathrm{~K}$ changes (figs 2-4).

\section{RELATION BETWEEN ANTIBODY PROFILE AND} CLINICAL STATUS

Minimal serological changes were observed for seven patients. Six of these had a clinically low
$123 \quad 345667891011$ $\begin{array}{llllllllll}2 & 3 & 4 & 5 & 6 & 7 & 8 & 9 & 10 & 11\end{array}$

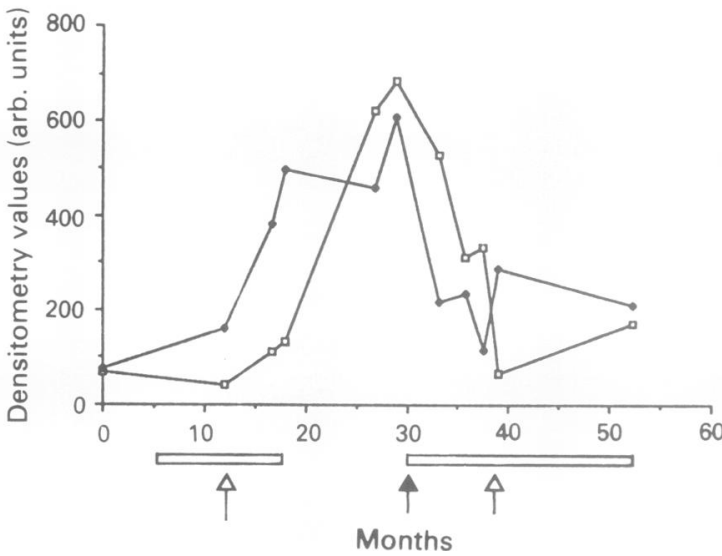

Figure 3 Detection of snRNP polypeptide antigens with sequentially obtained serum samples from patient 11 (table). (A) IgG antibodies reactive with snRNP polypeptide antigens in HeL a cell nuclear extract. (B) IgM antibodies reactive with snRNP polypeptide antigens in HeLa cell nuclear extract. (C) Plot of densitometry values obtained by scanning the blots shown in $(A)$ and $(B)$. ( $\square$ ) IgG antibodies reactive with the $70 K$ protein. ( $)$ IgM antibodies reactive with the $B / B^{\prime}$ protein. The closed arrow in the centre indicates the timepoint when exacerbation of disease was noted. The open arrows to the left and right indicate occasions when myositis was observed. The open bars indicate periods of treatment with prednisolone.

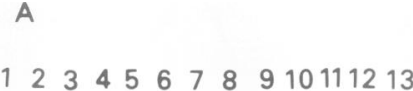

B

$\begin{array}{llllllllllllll}1 & 2 & 3 & 4 & 5 & 6 & 7 & 8 & 9 & 10 & 11 & 12 & 13\end{array}$

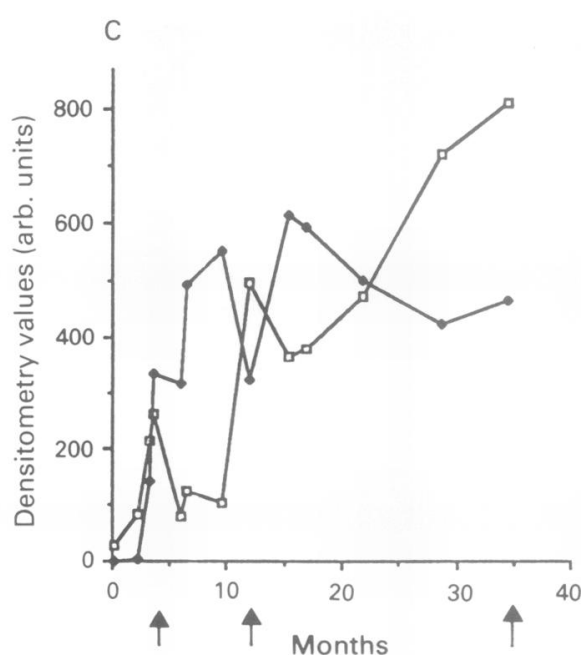

Figure 4 Detection of snRNP polypeptide antigens with sequentially obtained serum samples from patient 16 (table). (A) IgG antibodies reactive with snRNP polypeptide antigens in HeLa cell nuclear extract. (B) IgM antibodies reactive with snRNP polypeptide antigens in HeLa cell nuclear extract. $(C)$ Plot of densitometry values obtained by scanning the blots shown in $(A)$ and $(B)$. ( $\square)$ IgG antibodies reactive with the $70 K$ protein. ( $)$ IgM antibodies reactive with the $B / B^{\prime}$ protein. The arrows denote timepoints corresponding to exacerbation of disease. During the study period patient 16 had an active disease and was receiving continuous treatment with prednisolone. The first flare, leftmost arrow, was also treated with azathioprine. 
activity of disease during the period of study. In 23 patients increases in antibody levels or the appearance of new specificities were associated with clinical activity, mainly myositis, arthralgias, arthritis, leucopenia, thrombocytopenia, sicca symptoms, and serositis. The specificities with the most frequently occurring changes were the IgG antibodies to the $70 \mathrm{~K}$ protein and the $I g M$ antibodies to $B / B^{\prime}$ protein. Thus in 16 patients an exacerbation of disease was seen coinciding with an increase in IgG reactivity against the $70 \mathrm{~K}$ protein. An increased IgM reactivity against the $B / B^{\prime}$ protein was found to precede the clinical aggravation in 11 of these patients. Periods of decreased reactivity against snRNP were observed in the immunoblotting pattern from 21 patients. These occasions corresponded to periods of clinical remission, either spontaneous or following drug treatment.

\section{Discussion}

In this work immunoblotting was used to analyse sequentially obtained serum samples of 30 patients with connective tissue disease positive for antibody to RNP. The presence of antibodies of both the IgG and IgM isotypes reacting with the various snRNP proteins was examined. Semiquantitative data on variations in titre were obtained by densitometry of the blots. When probing for IgG antibodies the $70 \mathrm{~K}$ protein was detected by immunoblotting of HeLa cell nuclear extracts in 26 of 30 series of serum samples. For 17 of the patients positive for antibodies to the $70 \mathrm{~K}$ protein the diagnosis was mixed connective tissue disease (table). This confirms previous studies showing reactivity against the $70 \mathrm{~K}$ protein as the reactivity most strongly associated with antibodies to $\mathrm{RNP}^{67}$ and the diagnosis of mixed connective tissue disease. ${ }^{8-1014}$ Of the four serum samples lacking reactivity against the $70 \mathrm{~K}$ protein one showed reactivity against the snRNP A protein (table, No 29) whereas the remaining three (table, Nos 27, 28, and 30) did not recognise any snRNP protein.

All series of serum samples showed some level of variability over time in their pattern of IgG reactivity against the various snRNP proteins. A recurrent observation was that some serum samples showed modest changes in their overall reactivity in samples obtained on different occasions over several years. These serum samples were from patients not receiving any drug treatment during the observation period. They were usually clinically inactive or had manifestations not responsive to corticosteroids or immunosuppressive drugs, such as Raynaud's phenomenon or puffy hands.

More pronounced changes in IgG reactivity against snRNP were noted in serum samples from patients receiving constant or intermittent drug treatment. In these patients, corticosteroids and immunosuppressive drugs were mainly used in the treatment of recurrent pulmonary changes or relapsing polymyositis. The antibody changes seen in treated patients were manifested as an increased or decreased IgG reactivity primarily against the $70 \mathrm{~K}$ protein but could also include changing IgG reactivity against the A,
$\mathrm{C}$, and $\mathrm{B} / \mathrm{B}^{\prime}$ proteins. In a few patients recruitment of new specificities was observed. In neither instance was it possible to detect a common order of appearance or disappearance of specificities.

It appeared that an increased reactivity against snRNP correlated with an aggravation of the clinical status of the patient. In patients with mild aggravation of clinical symptoms or symptoms suppressed by drug treatment an increased reactivity against snRNP could still be observed. In no patient was a major change in clinical status observed without concomitant changes in antibody reactivity.

IgM antibodies reacting with snRNP proteins were present in 26 of the 30 series of serum samples tested. In contrast with the IgG results, IgM antibodies to the $70 \mathrm{~K}$ protein were only detected in nine patients. The most commonly observed specificity was antibodies to $\mathrm{B} / \mathrm{B}^{\prime}$ (table). IgM antibodies against the $\mathrm{A}$ and $\mathrm{C}$ proteins were also often represented, however. Interestingly, these specificities were present in some serum samples for seven years without switching to the IgG isotype. In other serum samples a coexistence between IgG and IgM antibodies to snRNP directed towards the same polypeptides was observed over a period of several years.

As for the IgG antibodies, all IgM antibodies to snRNP showed fluctuations in levels of staining intensity. These variations were more pronounced in patients with clinically active disease. In addition, in most patients the changes seemed to be correlated with major disease activity by preceding exacerbation of disease. In one patient (No 11 , fig $3 \mathrm{C}$ ) drug treatment (prednisolone) was initiated when myositis was observed and subsequently withdrawn after a clinically calm period. At this time the $\operatorname{IgM}$ reactivity against $\mathrm{B} / \mathrm{B}^{\prime}$ was increasing but the IgG reactivity to the $70 \mathrm{~K}$ protein was still unchanged. At the next observation point an increase in the level of the IgG reactivity against the $70 \mathrm{~K}$ protein was detected and eventually a flare of disease developed. The patient was treated with steroids again and improved clinically. The reactivities of $\operatorname{IgM}$ against $B / B^{\prime}$ and IgG against $70 \mathrm{~K}$ had then already peaked and were decreasing. From our observations it seems that the variation in the levels of antibody to snRNP rather than the level per se is coupled to disease activity. Especially noteworthy is the observation that changes in the level of the IgM antibodies against $B / B^{\prime}$ seem to precede the clinically observed flares, even though they might also reflect an increase in total IgM levels.

In conclusion, our observations suggest that for certain patients positive for autoantibody to RNP with an active connective tissue disease reactivity against the $70 \mathrm{~K}$ protein by IgG antibodies peaks at the time of exacerbation of disease. In addition, increased reactivity by $\operatorname{IgM}$ antibodies against the $B / B^{\prime}$ proteins seems to precede the increase in reactivity to the $70 \mathrm{~K}$ protein as well as the clinically evident exacerbation in the individual patient. A larger number of patients should be analysed prospectively to establish these observations. 
We gratefully acknowledge Dr Zdenka Heigl, Department of Clinical Immunology, Huddinge University Hospital for the antinuclear antibodies and counterimmunoelectrophoresis analyses and Ms Evi Mellquist for excellent technical assistance. Research support was provided by the Swedish Medical Research Council grant B92-16X-9927-01A to IP, by the Medical Research Council of the Swedish Life Insurance Companies to UN, by the Swedish Association against Rheumatism and the Professor Nanna Svartź trust to IL and by ASTRA Pharmaceutical Company to MW.

1 Tan E M. Antinuclear antibodies: diagnostic markers for autoimmune diseases and probes for cell biology. Adv Immunol 1989; 44: 93-151.

2 Sharp G C, Irwin W S, Tan E M, Gould R G, Holman H R. Mixed connective tissue disease: an apparently distinct rheumatic disease syndrome associated with a specific antibody to an extractable nuclear antigen (ENA). Am $\gamma$ Med 1972; 52: 148-59.

3 Tan E M, Kunkel H G. Characteristics of a soluble nuclear antigen precipitating with sera of patients with systemic lupus erythematosus. F Immunol 1966; 96: 464-71.

4 Lerner M R, Boyle J A, Mount S M, Wolin S L, Steitz J A Are snRNPs involved in splicing? Nature 1980; 283: 220-4.

5 Lerner M R, Steitz J A. Antibodies to small nuclear RNA complexed with proteins are produced by patients with systemic lupus erythematosus. Proc Natl Acad Sci USA 1979; 76: 5495-9.

6 Pettersson I, Hinterberger M, Mimori T, Gottlieb E, Steit J A. The structure of mammalian small nuclear ribonucleoproteins: identification of multiple protein components proteins: identifiction of multiple protein components reactive with anti-(Ui) ribonucleoprotein and

7 van Venrooij W J, Habets W J. Detection of nuclear antigen recognized by human autoantibodies. Scand $\mathcal{J}$ Rheumatol recognized by human aut

8 Habets W J, de Rooij D J, Hoet M H, van de Putte L B, van Venrooij W J. Quantitation of anti-RNP and anti-Sm antibodies in MCTD and SLE patients by immunoblotting. Clin Exp Immunol 1985; 59: 457-66.

9 Pettersson I, Wang G, Smith E I, et al. The use of immunoblotting and immunoprecipitation of $(U)$ small nuclear ribonucleoproteins in the analysis of sera of patients with mixed connective tissue disease and systemic lupus erythematosus. Arthritis Rheum 1986; 29: 986-96.

10 Takeda $Y$, Wang G S, Wang R J, et al. Enzyme-linked immunosorbent assay using isolated (U) small nuclear ribonumosorbent assay using isolated (U) small nuclear ribonucleoprotein polypeptides as antigens to investigate the clinical significance of autoantibodies to these poly-

11 peptides. Clin Immunol Immunopathol 1989; 50: 213-30. Hinterberger $M$, Pettersson I, Steitz J A. Isolation of smal
nuclear ribonucleoproteins containing U1, U2, U4, U5 and U6 RNAs. F Biol Chem 1983; 162: 2604-13.

12 Kallenberg C G M, Wouda A A, Hoet M H, van Venrooil W J. Development of connective tissue disease in patients presenting with Raynaud's phenomenon: a six year follow up with emphasis on the predictive value of antinuclear antibodies as detected by immunoblotting. Ann Rheum $D$ is 1988; 47: 634-41.

13 McHugh N, James I, Maddison P. Clinical significance of antibodies to a $68 \mathrm{kDa}$ UIRNP polypeptide in connective tissue disease 7 Rheumatol 1990; 17: 1320-8.

14 Reichlin M, van Venrooij W. Autoantibodies to the URNP particles; relationship to clinical diagnosis and nephritis. particles; relationship to clinical diagn

15 Lundberg I, Hedfors E. Clinical course of patients with anti-RNP antibodies. A prospective study of 32 patients. f Rheumatol 1991; 18: 1511-9.

16 de Rooij D J, van de Putte L B, Habets W J, Verbeek A L van Venrooij W J. The use of immunoblotting to detec antibodies to nuclear and cytoplasmic antigens. Scand $\mathcal{f}$ Rheumatol 1988; 17: 353-64.

17 de Rooij D J, Habets W J, van de Putte L B, Hoet $M$ H, Verbeek A L, van Venrooij W J. Use of recombinant RNP peptides $70 \mathrm{~K}$ and $A$ in an ELISA for measurement of antibodies in mixed connective tissue disease: a longitudinal follow up of 18 patients. Ann Rheum Dis 1990; 49: 391-5.

18 Hoffman R W, Rettenmaier L J, Takeda Y, et al. Human autoantibodies against the $70-\mathrm{kD}$ polypeptide of $U 1$ small nuclear RNP are associated with HLA-DR4 among connective tissue disease patients. Arthritis Rheum 1990; 33 : connective

19 Lundberg I, Nyman. U, Pettersson I, Hedfors E. Clinical manifestations and anti-(U1)snRNP antibodies. A prospective study of 29 anti-RNP antibody positive patients. $\operatorname{Br} \mathcal{F}$ Rheumatol. In press.

20 Nyman U, Lundberg I, Hedfors E, Pettersson I. Recom binant 70K protein used for determination of autoantigenic epitopes recognized by anti-RNP sera. Clin Exp Immunol 1990; 81: $52-8$. 